\title{
Toxicity mechanisms of onion (Allium cepa) extracts and compounds in multidrug resistant erythroleukemic cell line
}

\author{
Ana P. S. Votto 1,2 , Beatriz S. Domingues ${ }^{1,2}$, Michele M. de Souza3 ${ }^{3}$ Flavio M. R. da Silva Júnior ${ }^{2}$, \\ Sergiane S. Caldas ${ }^{4}$, Daza M. V. B. Filgueira ${ }^{1,2}$, Rosilene M. Clementin ${ }^{4}$, Ednei G. Primel ${ }^{4}$, \\ Adriana L. Vallochi ${ }^{5}$, Eliana B. Furlong ${ }^{3}$ and Gilma S. Trindade ${ }^{1,2 *}$ \\ 'Laboratório de Cultura Celular, Instituto de Ciências Biológicas, Universidade Federal do Rio Grande - FURG, Rio Grande, Brazil. \\ 2 Programa de Pós-graduação em Ciências Fisiológicas, Fisiologia Animal Comparada, FURG, Rio Grande, Brazil. \\ ${ }^{3}$ Laboratório de Ciência de Alimentos, Escola de Química e Alimentos, FURG, Rio Grande, Brazil. \\ ${ }^{4}$ Laboratório de Análises de Compostos Orgânicos e Metais, Escola de Química e Alimentos, FURG, Rio Grande, Brazil. \\ ${ }^{5}$ Fundação Oswaldo Cruz, Rio de Janeiro, Brazil.
}

\begin{abstract}
Onion (Allium cepa) is being studied as a potential anticancer agent, but little is known regarding its effect in multidrug resistance (MDR) cells. In this work, the cytotoxicity of crude onion extract (OE) and fractioned extract (aqueous, methanolic and ethyl acetate), as well as some onion compounds (quercetin and propyl disulfide) were evaluated in Lucena MDR human erythroleukemic and its K562 parental cell line. The capacity of OE to induce apoptosis and/or necrosis in these cells, the possible participation of oxidative stress and DNA damage were also assessed. Similar sensitivities were obtained for both tumoral cells, however only OE caused significant effects in the cells. In K562 cells, a significant increase of apoptosis was verified while the Lucena cells experienced a significant increase of necrosis. An antioxidant capacity was verified for OE discarding oxidative damage. However, OE provoked similar significant DNA damage in both cell lines. Thus, the OE capacity to overcome the MDR phenotype suggests anti-MDR action of OE.
\end{abstract}

Key terms: antioxidant; apoptosis and/or necrosis; DNA damage; MDR phenotype; onion (Allium cepa); tumoral cell.

\section{INTRODUCTION}

Natural products with high medicinal values are gaining much importance in light of the serious side effects posed by drugs of chemical origin (Sreekanth et al., 2007). There is a substantial body of evidence that a high intake of antioxidant-rich foods, especially fruits and vegetables is associated with a reduced risk of most cancers (Borek, 2005). According to Corzo-Martínez et al. (2007) although the minimum daily intake required to reduce cancer risk remains to be determined, garlic and onion intake can offer protection against cancer development, and the use of these as therapeutic agents seems to be very safe, since all adverse effects previously described appear with excessive and prolonged consumption.

Onion (Allium cepa. Linn) is commonly used in our daily diet and has also been used as a folk remedy for its antiinfective properties and other beneficial effects. It has been studied for therapeutic use as an antioxidant and anti-cancer agent (Augusti, 1996; Saleheen et al., 2004; Santas et al., 2008).

The nutritional composition of onion is very complex. It has been shown that it is one of the major sources of dietary flavonoids in many countries. Specifically, onion has been characterized for its flavonol quercetin and quercetin derivates. Moreover, it is rich in other bioactive compounds such as fructooligosaccharides and sulphur compounds (Roldán et al., 2008). Among the organosulphur compounds identified in onion oil and powder is dipropyl disulfide, one of the major isolated chemicals (Seki et al., 2000; Teyssier et al., 2001).
The scientific literature has demonstrated that different extracts and compounds of onion produce significant biological effects. Seki et al. (2000) have demonstrated that onion oil inhibited the growth of the HL-60 human promyelocytic leukemia cell line by inducing the differentiation of HL-60 into mature cells of granulocytic lineage. As well, sodium n-propyl thiosulfate (NPTS), an alk(en)yl thiosulfate present in Allium cepa, suppressed the growth of HL-60 cells through the induction of apoptosis initiated by oxidative stress, indicating that the alk(en)yl thiosulfates account partly for the anti-carcinogenic properties of onion and have the potential to prevent tumors (Chang et al., 2005).

Considering the importance of understanding molecular and cellular processes involved in tumoral development, it is interesting to assess the possible effects of onion on this process. Additionally, considerable attention has been dedicated in the last decade overcoming the mechanisms of drug resistance. The observation that some compounds of natural origin are capable of modulating multidrug resistance (MDR) proteins has called attention to these substances (Braga et al., 2007).

The development of different types of resistance is one of the major causes of chemotherapeutic failures in cancer treatment (Fernandes et al., 2005). The MDR phenotype is a phenomenon by which tumors that initially respond to a prescribed chemotherapy acquire resistance, not only to the drugs utilized in the treatment, but also to other nonchemically related drugs (Gottesman and Pastan, 1993). Various factors can lead to MDR phenotype acquisition, but the best understood mechanism of MDR is the one

* Corresponding author: Gilma S. Trindade, Phone/Fax: +55 5332935195 / +55 5332336848 , E-mail address: gilma.trindade@gmail.com, Instituto de Ciências Biológicas, Universidade Federal do Rio Grande - FURG, Cx. Postal, 474, 96201-900 Rio Grande/RS - Brazil

Received: January 28, 2010. In revised form: April 26, 2010. Accepted: June 25, 2010. 
conferred by the membrane P-glycoprotein (Pgp) (Ford and Hait, 1990), which acts by pumping several unrelated drugs out of the cells (Gottesman and Pastan, 1993). Rumjanek et al. (1994) established a leukemic MDR cell line using vincristine, according to the method of Tsuruo et al. (1983), and designated the transformed cell line K562-Lucena (Lucena).

Thus, the objective of this work was to compare the sensitivity of the cell lines that express, or do not express, the MDR phenotype to crude onion extract (OE), the effect of different fractions and some compounds of this extract, as well as to verify the possible cytotoxic mechanisms of OE.

\section{MATERIALS AND METHODS}

\subsection{Preparation of crude onion (Allium cepa) extract (OE)}

The crude onion extract (OE) was prepared using onions (Petroline variety) obtained from the Coxilha region, located in the $5^{\text {th }}$ district of Rio Grande, RS (southern Brazil). The onions were crushed and centrifuged at 3,000 rpm for 15 minutes. The supernatant was filtered and sterilized through a $0.22 \mu \mathrm{m}$ membrane filter (Millipore), and stored at $-80^{\circ} \mathrm{C}$. To estimate extract concentration, samples were submitted to a speed vac evaporator. The final product was quantified relating dry weight to volume $(\mathrm{dw} / \mathrm{v})$. The resultant stock concentration was $115 \mathrm{mg} / \mathrm{ml}$. The OE concentrations tested in the cell lines were $0.5 ; 1 ; 2$; 4 and $8 \mathrm{mg} / \mathrm{ml}$.

\subsection{Fractionation of $O E$ and Phenol Contents}

The OE was lyophilized and cold temperature extraction of the phenolic compounds was performed with water, ethyl acetate or methanol under horizontal agitation, followed by filtration at ambient temperature. The total phenolic content of OE was determined by the Folin-Ciocalteau method, using quercetin as standard (Furlong et al., 2003). Briefly, an aliquot of $500 \mu \mathrm{l}$ of $\mathrm{OE}$ was dissolved in $500 \mu \mathrm{l}$ of water and mixed with $4.5 \mathrm{ml}$ of $\mathrm{Na}_{2} \mathrm{CO}_{3} 4 \%$ for 1 minute and then placed in water bath at $40^{\circ} \mathrm{C}$ for 15 minutes. The homogenate was then agitated for 30 seconds in an ultrasonic bath with $500 \mu$ l of Folin-Ciocalteau reagent diluted in distilled water (1:2). After 10 minutes, the absorbance was measured at $660 \mathrm{~nm}$. The total phenol content was determined by interpolation of sample absorbance against the analytical curve of the quercetin standard. The data were expressed as $\mathrm{mg}$ of total phenols/g of OE. The total phenolic content verified in the OE was $11.3 \mathrm{mg}$ phenols $/ \mathrm{g}$ OE.

The phenol concentrations of aqueous fraction used in the cells were the same present in each OE concentration previously tested in the cells. Based on this, the phenol concentrations of the aqueous fraction used were $4.375 ; 8.75$; $17.5 ; 35$ and $70 \mu \mathrm{g} / \mathrm{ml}$. The same volume of extracts of aqueous fraction were used for both methanol and ethyl acetate fractions, which determined the concentrations of 5; $10 ; 20 ; 40$ and $80 \mu \mathrm{g} / \mathrm{ml}$ of phenols for the methanolic fraction, and $0.263 ; 0.525 ; 1.05 ; 2.1$ and $4.2 \mu \mathrm{g} / \mathrm{ml}$ of phenols for the ethyl acetate fraction.

\subsection{Chromatographic Analysis}

\subsubsection{OE characterization by GC-MS}

According to Roldán et al. (2008) the major substances of onion are sulphur compounds and flavonols. Thus, the first step was to characterize the chemical profile of OE in general terms. This experiment were carried out in a Shimadzu gas chromatograph-mass spectrometer model GCMSQP2010Plus, equipped with a capillary column Crossbond $5 \%$ diphenyl/95\% dimethyl polysiloxane (Restek, $30 \mathrm{~m} \times 0.25$ $\mathrm{mm}$ i.d. $x 0.25 \mathrm{um})$. The operating conditions were as follows: injector temperature, $250{ }^{\circ} \mathrm{C} ; \mathrm{H}_{\mathrm{e}}$ flow rate, $1 \mathrm{~mL} \mathrm{~min}^{-}$ 1; oven temperature, $60-260{ }^{\circ} \mathrm{C}$ raised by $6{ }^{\circ} \mathrm{C} \mathrm{min}^{-1}$ and injection volume of $1 \mu \mathrm{L}$. All injections were made in the split mode (split ratio 50:1). The operational parameters of the mass spectrometer were as follows: ionization voltage, 70 $\mathrm{eV}$; source temperature, $200{ }^{\circ} \mathrm{C}$; scan region, $50-250 \mathrm{~m} / \mathrm{z}$. The interface temperature was at $250{ }^{\circ} \mathrm{C}$. The identification of compounds was accomplished by comparing the mass spectra data with those of compounds available from NIST library.

\subsubsection{Quercetin}

For quercetin determination, a hydrolysis of the extract was made based on Wach et al., 2007. The identification of quercetin (CAS Reg. No. 849061-97-8) was carried out with an HPLC system from Waters, which consisted of a Waters 600 pump model, associated with a Waters 2996 Photodiode Array Detector, Rheodyne $20 \mu \mathrm{l}$ loop injector, connected to an Empower PDA software for data acquisition. The

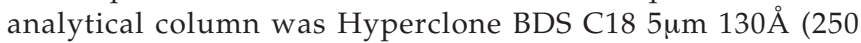
x $4.6 \mathrm{~mm} \mathrm{I.D),} \mathrm{from} \mathrm{Phenomenex} \mathrm{(Torrance,} \mathrm{CA,} \mathrm{US).} \mathrm{The}$ mobile phase consisted of methanol (Mallinckrodt), acetonitrile (Mallinckrodt) and Milli-Q water acidified to pH 2.5 with phosphoric acid (Merck) (1:1, v/v) (40:15:45, v/ v). Water was purified with a Direct-Q UV3 ${ }^{\circledR}$ (resistivity $18.2 \mathrm{M} \Omega \mathrm{cm}$ ) water purification system (Millipore, Bedford, MA, USA). The chromatograph was operated in the isocratic mode and the flow rate was $1 \mathrm{ml} / \mathrm{min}$. Identification was based on retention time and UV-VIS spectra by comparison to standard commercial quercetin (Sigma). Quantification was carried out by the integration of the peak using the external standard method. The chromatographic profile of OE was compared to that of quercetin in standard solution.

The quercetin concentration in the $\mathrm{OE}$ was $27.5 \mu \mathrm{g} / \mathrm{ml}$ and the concentrations used in the tests $(0.125 ; 0.25 ; 0.5 ; 1$ and $2 \mu \mathrm{g} / \mathrm{ml}$ ) were equivalent to quercetin concentration present in each OE concentration previously tested.

\subsubsection{Propyl disulfide}

The propyl disulfide (CAS Reg. No. 629-19-6) (Sigma) analysis was performed with a Shimadzu gas chromatograph-mass spectrometer model GCMS-QP2010Plus equipped with a capillary column Crossbond 5\% diphenyl/ 95\% dimethyl polysiloxane (Restek, $30 \mathrm{~m}$ x $0.25 \mathrm{~mm}$ i.d. $x$ $0,25 \mathrm{um})$. The operating conditions were as follows: injector temperature, $250{ }^{\circ} \mathrm{C} ; \mathrm{H}_{\mathrm{e}}$ flow rate, $1 \mathrm{~mL} \mathrm{~min}{ }^{-1}$; oven temperature, $60-170{ }^{\circ} \mathrm{C}$ raised by $6{ }^{\circ} \mathrm{C} \mathrm{min}^{-1}$ and injection 
volume of $1 \mu \mathrm{L}$. All injections were made in the splitless mode. The operational parameters of mass spectrometer were as follows: ionization voltage, $70 \mathrm{eV}$; source temperature, $200{ }^{\circ} \mathrm{C}$; scan region, $50-250 \mathrm{~m} / \mathrm{z}$. The interface temperature was at $250{ }^{\circ} \mathrm{C}$. In the SIM mode the ions monitored were $\mathrm{m} / \mathrm{z} 150$ and 108 .

The propyl disulfide concentration in the OE was 0.23 $\mu \mathrm{g} / \mathrm{ml}$ and the concentrations tested in the cells $(1 ; 2 ; 4 ; 8 \mathrm{e}$ $16 \mathrm{ng} / \mathrm{ml}$ ) were equivalent to propyl disulfide concentration present in each OE concentration previously tested.

\subsection{Cells and culture conditions}

The tumoral cells were obtained from the Tumoral Immunology Laboratory of the Medical Biochemistry Department of the Rio de Janeiro Federal University, Brazil. The K562 cells were grown in RPMI 1640 (Gibco) medium supplemented with sodium bicarbonate $(0.2 \mathrm{~g} / \mathrm{l})$ (Vetec), Lglutamine $(0.3 \mathrm{~g} / \mathrm{l})$ (Vetec), Hepes $(25 \mathrm{mM})$ (Acros) and $\beta$ mercaptoethanol $\left(5 \times 10^{-5} \mathrm{M}\right)$ (Sigma), with $10 \%$ fetal bovine serum (Gibco), plus 1\% of antibiotic (penicillin $100 \mathrm{U} / \mathrm{ml}$ ) and streptomycin $(100 \mu \mathrm{g} / \mathrm{ml})$ (Gibco) and antimycotic $(0.25$ $\mu \mathrm{g} / \mathrm{ml}$ ) (Sigma), in disposable plastic flasks, at $37^{\circ} \mathrm{C}$. The MDR Lucena cells were grown under the same conditions, but in the presence of $60 \mathrm{nM}$ vincristine (VCR) (Sigma), in order to preserve the MDR phenotype.

\subsection{Assessment of the sensitivity of cells}

The cells were grown for two days (K562) and for three days (Lucena) before the beginning of experiments (Trindade et al., 1999). The cells were centrifuged, washed with phosphate buffer saline $\left(\mathrm{Ca}^{+2}\right.$ and $\mathrm{Mg}^{+2}$ free) (PBS) and suspended in medium without $\beta$-mercaptoethanol to a final concentration of $5 \times 10^{5}$ cells $/ \mathrm{ml}$. The cells were treated in medium with different concentrations of OE, fractioned extracts, quercetin or propyl disulfide plus a control group that received the same volume of sterile water and incubated at $37^{\circ} \mathrm{C}$ in culture plates. During the experiments, no VCR was added to Lucena cell cultures. Cell viability was assessed by 3-(4,5-dimethylthiazol-2-yl)2,5diphenyltetrazolium (MTT; Sigma) assay after 0 h, 24 h, 48 $\mathrm{h}$ and $72 \mathrm{~h}$ of exposure according to protocol (Trindade et al., 1999). Briefly, after incubation the cells were washed with PBS and $200 \mathrm{ml}$ RPMI 1640 medium $\beta$ mercaptoethanol free and $20 \mu \mathrm{l}$ of MTT $(5 \mathrm{mg} / \mathrm{ml})$ was added to each well. The plates were incubated for $3 \mathrm{~h}$ at 37 ${ }^{\circ} \mathrm{C}$. The medium was removed and formazan crystals were dissolved in $200 \mu$ l of dimethylsulfoxide (DMSO, Sigma) with gentle shaking. The absorbance values at $490 \mathrm{~nm}$ were determined on a multiwell plate reader (ELX 800 Universal Microplate Reader, Bio-TEK).

The results obtained in this section indicated the type extract $(\mathrm{OE})$ and the different concentrations utilized in each subsequent test.

\subsection{Detection of apoptosis/necrosis by annexin-V/PI staining}

Quantitative determination of apoptotic and/or necrotic cells was performed after incubation with 1, 2 and $4 \mathrm{mg} / \mathrm{ml}$ of $\mathrm{OE}$ for $24 \mathrm{~h}$ through a reaction with Annexin V-FITC and Propidium Iodide (PI). The control and treated cells $\left(2 \times 10^{5}\right.$ cell $/ \mathrm{ml}$ ) were washed twice with PBS, suspended in $250 \mu \mathrm{l}$ of binding buffer diluted 10x (0.1 M Hepes/ NaOH ( $\mathrm{pH} 7.4), 1.4$ $\mathrm{M} \mathrm{NaCl}, 25 \mathrm{mM} \mathrm{CaCl}_{2}$ ) plus $40 \mu \mathrm{l}$ of Annexin V-FITC solution diluted in binding buffer (1:10) and incubated for 20 min in the dark. PI $(2.5 \mu l)$ was then added and cell acquisition was detected using a flow cytometer (FACSCALIBUR, BD Biosciences). To detect apoptosis/ necrosis by flow cytometry, the percentage of total cells was calculated using the Cell Quest Pro program. Annexin VFITC+/PI- cells were counted as early apoptosis; Annexin VFITC+/PI+ and Annexin V-FITC-/PI+ cells were counted as necrosis (Lankoff et al., 2003).

\subsection{Antioxidant capacity of $O E$}

2.7.1. Assessment of intracellular Reactive Oxygen Species (ROS) formation

The K562 and Lucena cells $\left(5 \times 10^{5}\right.$ cell/ml) were treated in medium with $0.5 ; 1$ and $2 \mathrm{mg} / \mathrm{ml}$ of $\mathrm{OE}$ and incubated at $37^{\circ} \mathrm{C}$ during $24 \mathrm{~h}$. Then the cells were washed with PBS (twice) and incubated for $30 \mathrm{~min}$ at $37{ }^{\circ} \mathrm{C}$ with the fluorogenic compound $2^{\prime}, 7^{\prime}$-dichlorofluorescin diacetate $\left(\mathrm{H}_{2} \mathrm{DCF}-\mathrm{DA}\right)$ at a final concentration of $40 \mu \mathrm{M}$. After the loading with $\mathrm{H}_{2}$ DCF-DA, the cells were washed with PBS twice and then suspended in fresh PBS. Aliquots of $160 \mu \mathrm{l}$ of each sample (five replicates) were placed into an ELISA plate and the fluorescence intensity was determined for $90 \mathrm{~min}$ at $37^{\circ} \mathrm{C}$, using a fluorometer (Victor 2, Perkin Elmer), with an excitation and emission wavelength of 485 and $520 \mathrm{~nm}$, respectively. ROS levels were expressed in terms of fluorescence area, after fitting fluorescence data to a second order polynomial and integrating between 0 and $90 \mathrm{~min}$ in order to obtain its area.

\subsubsection{Antioxidant capacity against peroxyl radicals (ACAP)}

The K562 and Lucena cells $\left(5 \times 10^{5}\right.$ cell/ml) received the same OE treatment employed in the ROS assay, then the cells were washed with PBS (twice) and frozen at $-80^{\circ} \mathrm{C}$ until use. Each pellet was then suspended in PBS and crushed on ice. The homogenate was centrifuged $(10,000 \mathrm{x}$ g) at $4^{\circ} \mathrm{C}$, for $20 \mathrm{~min}$. Aliquots of $15 \mu \mathrm{l}$ of each supernatant (five replicates) were placed into an ELISA plate with $120 \mu \mathrm{l}$ buffer (Hepes, $\mathrm{KCl}, \mathrm{MgCl}_{2}$ and water), and $10 \mu \mathrm{l}$ of water or 2,2'-azobis(2metilpropionamidina) (ABAP) and $20 \mu \mathrm{l}$ of $\mathrm{H}_{2}$ DCF-DA. The fluorescence intensity was determined for $60 \mathrm{~min}$ at $37^{\circ} \mathrm{C}$, using a fluorometer (Victor 2, Perkin Elmer), with an excitation and emission wavelength of 485 and $520 \mathrm{~nm}$, respectively. The fluorescence data was fit to a second order polynomial and integrating between 0 and 60 min in order to obtain the fluorescence area, and the antioxidant capacity was expressed as the inverse of the difference of fluorescence area with and without ABAP (Amado et al., 2009).

\subsection{Capacity of OE to induce DNA damage}

The K562 and Lucena cells $\left(5 \times 10^{5}\right.$ cell $\left./ \mathrm{ml}\right)$ were treated in medium with $2 \mathrm{mg} / \mathrm{ml}$ of $\mathrm{OE}$ and incubated at $37^{\circ} \mathrm{C}$ for $24 \mathrm{~h}$. DNA damage was evaluated by the alkaline single cell electrophoresis (comet) assay, performed as described by 
Singh et al. (1988) and Steinert et al. (1998), with some modifications. An aliquot $(80 \mu \mathrm{l})$ of cell suspension of each sample $\left(5 \times 10^{5} \mathrm{cell} / \mathrm{ml}\right)$ was mixed with $60 \mu \mathrm{l}$ of $1 \%$ low melting point agarose and added to fully frozen slides that had been covered with a layer of $1.5 \%$ normal melting point agarose. Following the solidification of the new layer, cells on the slides were lysed with $(2.5 \mathrm{M} \mathrm{NaOH}, 0.1 \mathrm{M}$ EDTA, $0.01 \mathrm{M}$ Tris, $1 \%$ Triton X-100, and 10\% dimethyl sulfoxide, $\mathrm{pH} 10$ ) overnight at $4^{\circ} \mathrm{C}$. Subsequently, samples were placed in the electrophoresis solution $(300 \mathrm{mM} \mathrm{NaOH}$ and $1 \mathrm{mM}$ EDTA, pH 13) for 30 min to allow DNA unwinding. Then, electrophoresis was performed for $20 \mathrm{~min}$ at $25 \mathrm{~V}(0.83 \mathrm{~V} /$ $\mathrm{cm}$ ) and $280 \mathrm{~mA}$. Finally, the slides were neutralized with 0.4 M Tris buffer ( $\mathrm{pH} 7.5)$, stained with $30 \mu \mathrm{L}$ of Sybr Gold (1:10,000; Molecular Probes) and analyzed using a fluorescence microscope (Olympus BX50) connected to a CCD camera (Pro-Series, High Performance) and coupled to commercial software for image acquisition. A total of 50 nuclei were randomly selected and photographed on each slide. The nuclei were analyzed by CASP software and DNA damage was represented by Olive tail moment (OTM) (Konca et al., 2003).

\subsection{Statistical analysis}

In all cases, three independent experiments were performed using triplicates in each experiment. Data are expressed as mean \pm standard error and analyzed with ANOVA followed by Tukey's multiple range test. Significance level was fixed at $\mathrm{p}<0.05$.

\section{RESULTS}

\subsection{Onion extracts characterization by GC-MS}

Figure 1 shows the general GC chromatography highlighting the separation of sulphur compounds of OE. We observed that most of the compounds were thiosulfinates and organosulfur compounds and are the same as observed in previous works (Seki et al., 2000; Teyssier et al., 2001). Some of them were 1,3-Dithiane, 2,2-dimethyl- (1), 2-vinyl-1,3dithiane (2), diallyl disulphide (3), 2-Ethylidene[1,3]dithiane (4), 2,4-Dimethylthiophene (5), [1,2,3,4]Tetrathiine (6), 1Propene, 1-(methylthio)-,(E)- (7), 1-Propene, 1-(methylthio),(Z)- (8), 5-methylthiophen-3-ylamine (9), thiophene, 2-ethyl5-[(2-ethylbutyl)thio] (10) and dimethyl tetrasulphide (11). Compounds belonging to other classes, such as phenols (Phenol, 2,6-bis(1,1-dimethylethyl)-4-methyl- (12) and carboxilic acids (1,2-Benzenedicarboxylic acid, bis(2methylpropyl) Ester) (13) were also identified.

\subsection{Assessment of the sensitivity of cells}

\subsubsection{Sensitivity to $O E$}

Similar sensitivity results were obtained for both tumoral cell lines. The two lower concentrations of $\mathrm{OE}$ did not exhibit a significant difference in relation to the control cells. However, the concentration of $8 \mathrm{mg} / \mathrm{ml}$ was already cytotoxic at $24 \mathrm{~h}$ of treatment and the concentrations of 2 and $4 \mathrm{mg} / \mathrm{ml}$ were cytotoxic from $48 \mathrm{~h}$ of incubation (Fig. 2A,B).

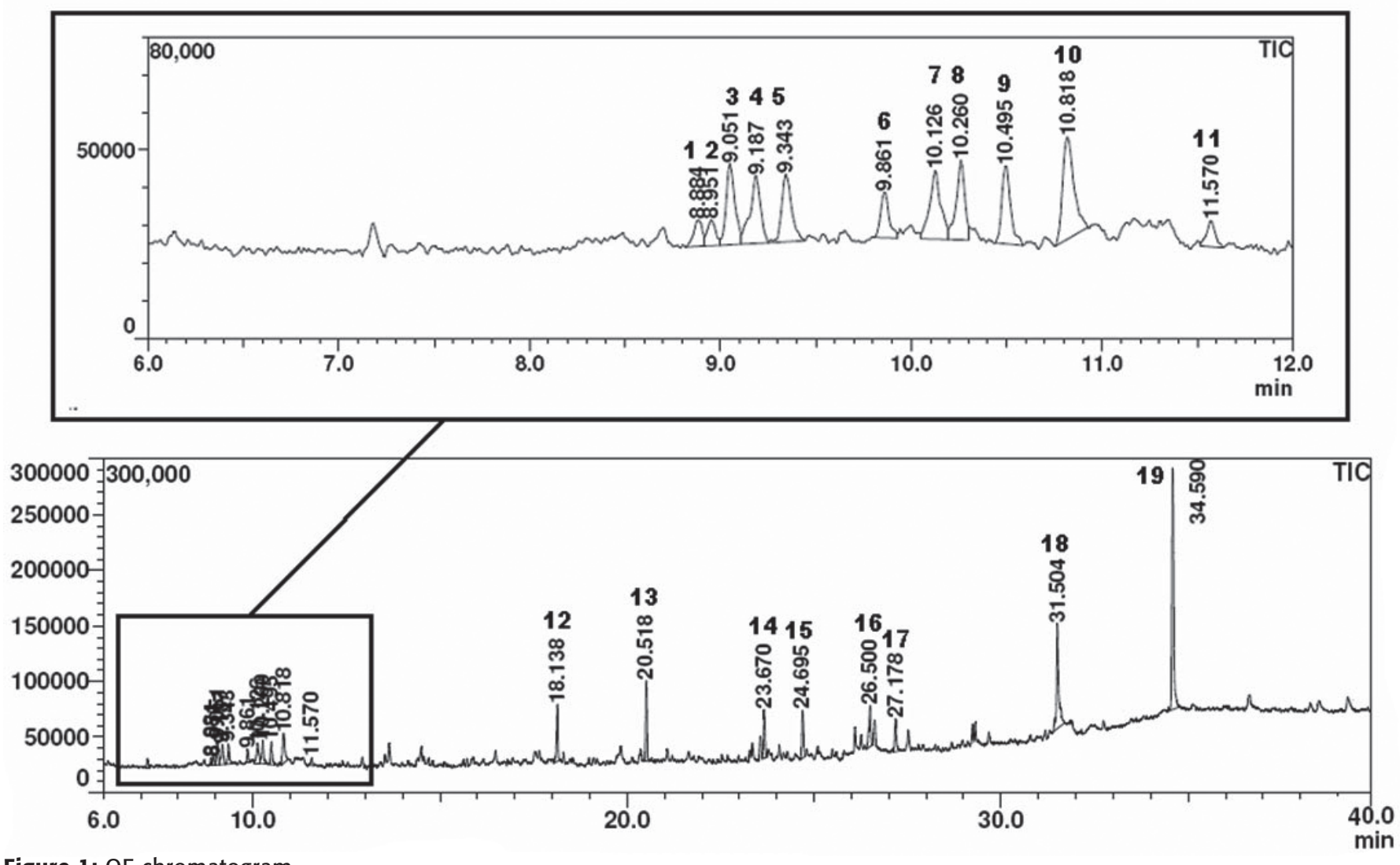

Figure 1: OE chromatogram

Legend: GC-MS chromatogram of the OE (Zoom: region of the elution of the sulphur compounds). 


\subsubsection{Sensitivity to fractioned extracts}

Similar sensitivity results were obtained for both tumoral cell lines in all extracts tested. The aqueous and methanolic extracts showed a significant cytotoxic effect only in the highest concentration after $72 \mathrm{~h}$ of incubation (Fig. 3A-D). The ethyl acetate extract caused no significant cytotoxic effects at any concentration (Fig. 3E,F).
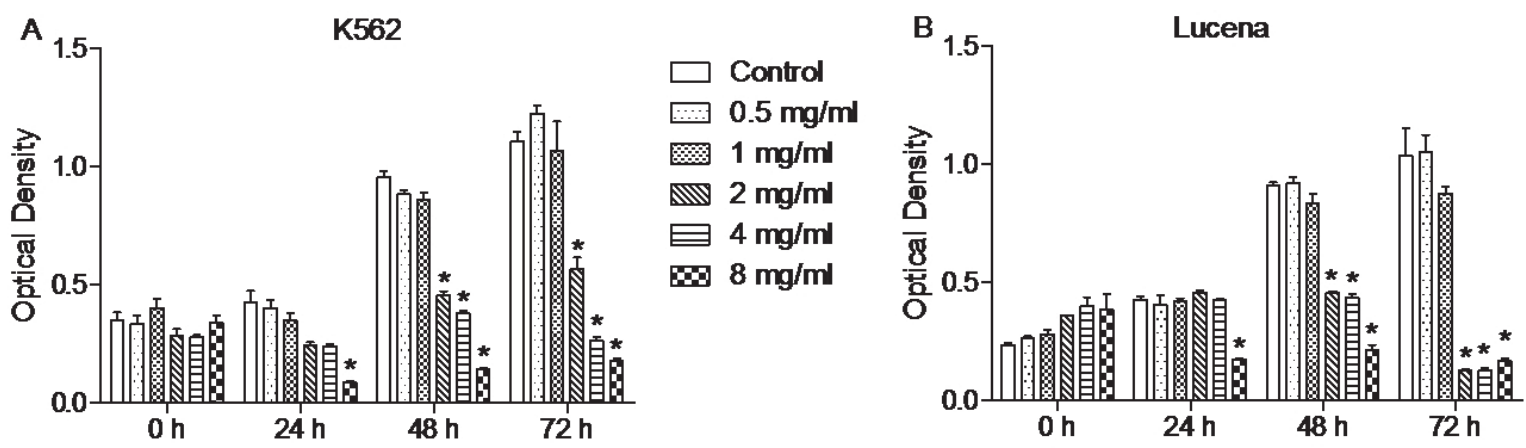

Figure 2: OE effect on cell viability

Legend: Optical density of viable of K562 (non MDR phenotype) cells (A) and Lucena (MDR phenotype) cells (B) by the MTT assay, immediately (0), 24, 48 and $72 \mathrm{~h}$ after exposure to different concentrations of OE. Data are expressed as mean +1 standard error. ${ }^{*}-$ indicates significant difference from the respective control at each exposure time $(p<0.05)$.
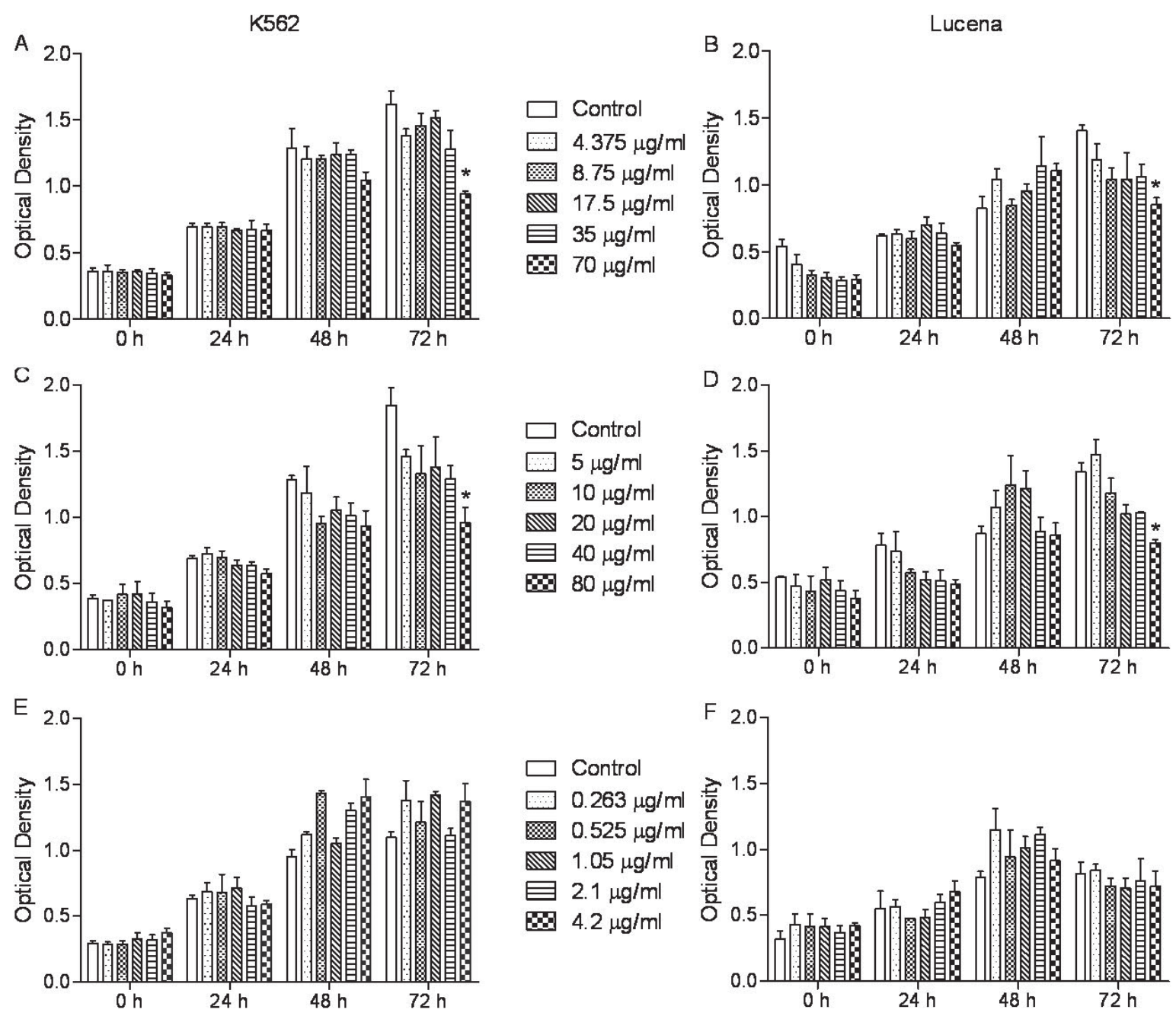

Figure 3: Effect of onion fractioned extracts on cell viability

Legend: Optical density of viable of K562 and MDR Lucena cells by the MTT assay, immediately (0), 24, 48 and 72 h after exposure to different concentrations of fractioned extracts. (A) K562 and (B) Lucena cells exposed to aqueous fraction; (C) K562 and (D) Lucena cells exposed to methanolic fraction; and (E) K562 and (F) Lucena cells exposed to ethyl acetate fraction. Data are expressed as mean +1 standard error. * - indicates significant difference from the respective control at each exposure time $(p<0.05)$. 


\subsubsection{Sensitivity to quercetin and propyl disulfide}

Since quercetin derivatives comprised more than $90 \%$ of the total flavonol content in onions (Slimestad et al., 2007) and quercetin was identified and quantified in the extract (Fig. $4 \mathrm{~A})$; the sensitivity to quercetin of the cells was evaluated.

On the other hand, the present OE showed several sulphur compounds and considering that propyl disulfide is one of the most important compounds in onion (Teyssier et al., 2001) it was determined and quantified in the SIM mode. Figure 4B shows a chromatogram of standard solution with $0.5 \mathrm{mg} / \mathrm{L}$ propyl disulfide (4B1) and a chromatogram of the determination of propyl disulfide in the $\mathrm{OE}$ (4B2). The same figure also shows the mass spectrum (4B3).

No significant cytotoxic effects were observed in either cell line treated with quercetin (Fig. 5A,B) or propyl disulfide (Fig. 5C,D).

\subsection{Detection of apoptosis/necrosis provoked by $O E$}

In the K562 cells, a significant increase in the percentage of apoptotic cells at a concentration of $4 \mathrm{mg} / \mathrm{ml}$ of $\mathrm{OE}$ was observed when compared to the control (Fig. 6A). The Lucena cells showed a significant increase in the percentage of necrotic cells at the same concentration (Fig. 6B).

\subsection{Antioxidant capacity of $\mathrm{OE}$}

A significant decrease in ROS levels was verified in both cell lines at a concentration of $2 \mathrm{mg} / \mathrm{ml}$ in relation to respective controls (Fig. 7A). However, a significant increase in the ACAP value at a concentration of $2 \mathrm{mg} / \mathrm{ml}$ was only verified in the $\mathrm{K} 562$ cells when compared to the control (Fig. 7B).

\subsection{DNA damage}

The cell lines exhibited significant DNA damage at a concentration of $2 \mathrm{mg} / \mathrm{ml}$ of $\mathrm{OE}$ when compared to respective controls, and this effect was similar for both cell lines (Fig. 8).

\section{DISCUSSION}

Based on the potential properties of onion, this work began analyzing OE effects on MDR and non-MDR erythroleukemic cell lines. The results clearly demonstrate the cytotoxic capacity of $\mathrm{OE}$. This led us to investigate which fraction or compounds of the extract is responsible for the cytotoxic effect. However, neither the fractioned extracts (aqueous, methanolic and ethyl acetate) or the purified compounds (quercetin and propyl disulfide) showed effects comparable

\section{A}
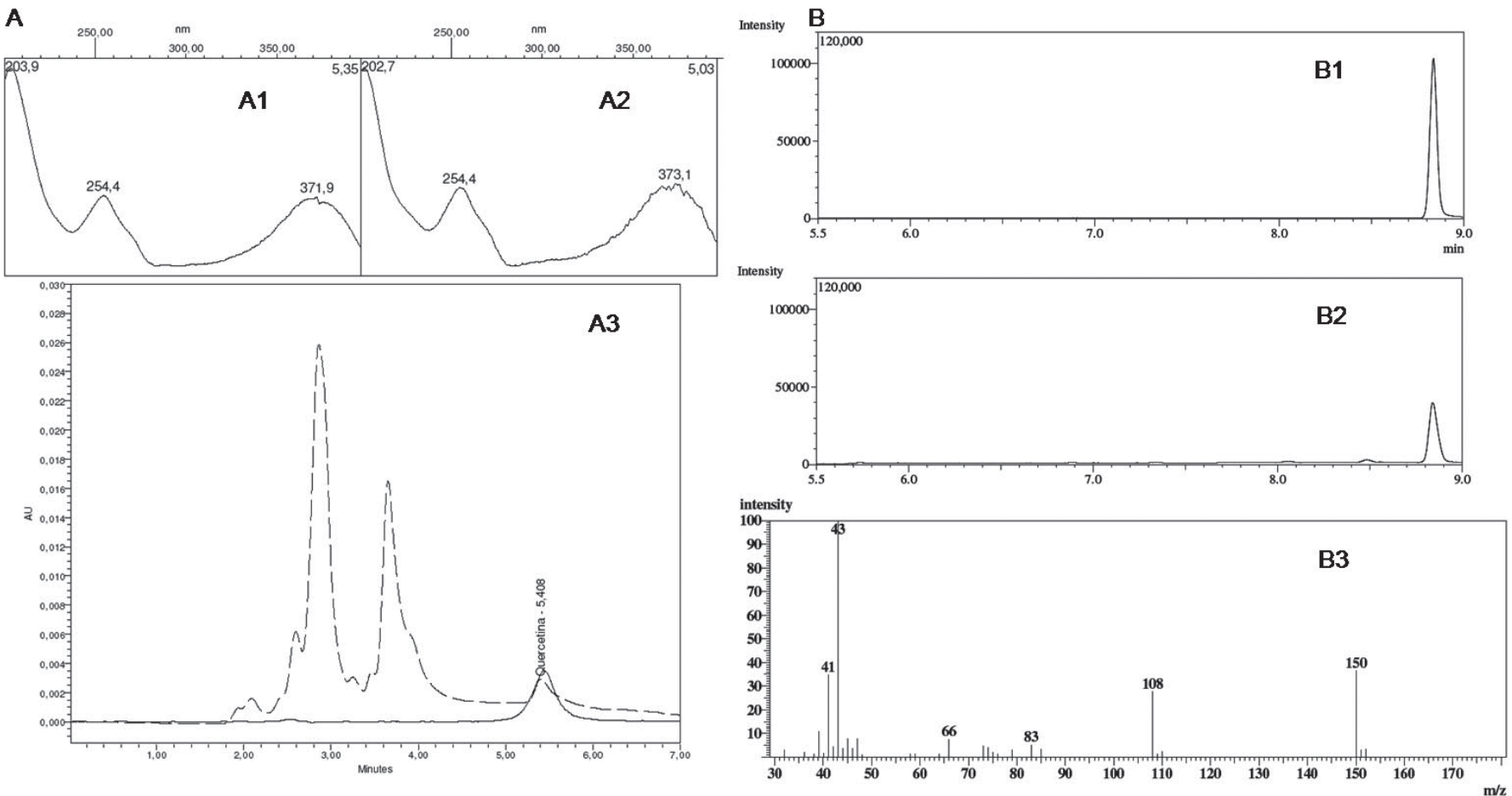

Figure 4: Chromatograms of quercetin and propyl disulfide

Legend: Chromatograms of quercetin (A) and propyl disulfide (B). Quercetin standard $1 \mathrm{mg} / \mathrm{L}$ (line) and OE (dotted line) (A3); and UV-vis absorbing spectrograms of (A1) quercetin standard and (A2) OE; and chromatogram of standard solution with $0.5 \mathrm{mg} / \mathrm{L}$ of propyl disulfide (B1), sample analyses (B2) and spectrum of the standard solution in the full scan mode (B3). 
to OE. Only some fractions presented significant effects, but in higher concentrations and with longer exposure time. These results suggest that the OE effect could be the result of synergistic action of several compounds. Hollman et al. (1997) demonstrated that conjugating quercetin with glucose enhanced its absorption from the small gut. According to Teyssier et al. (2001), sulphur compounds and glycosides of quercetin are present simultaneously in onion and the modulating effect of onion consumption on drugmetabolizing enzymes could be attributed partly to the sulphur compounds. Therefore, the bioavailability of quercetin could be better when ingested through the onion and the different components present in onion probably have an additive action.
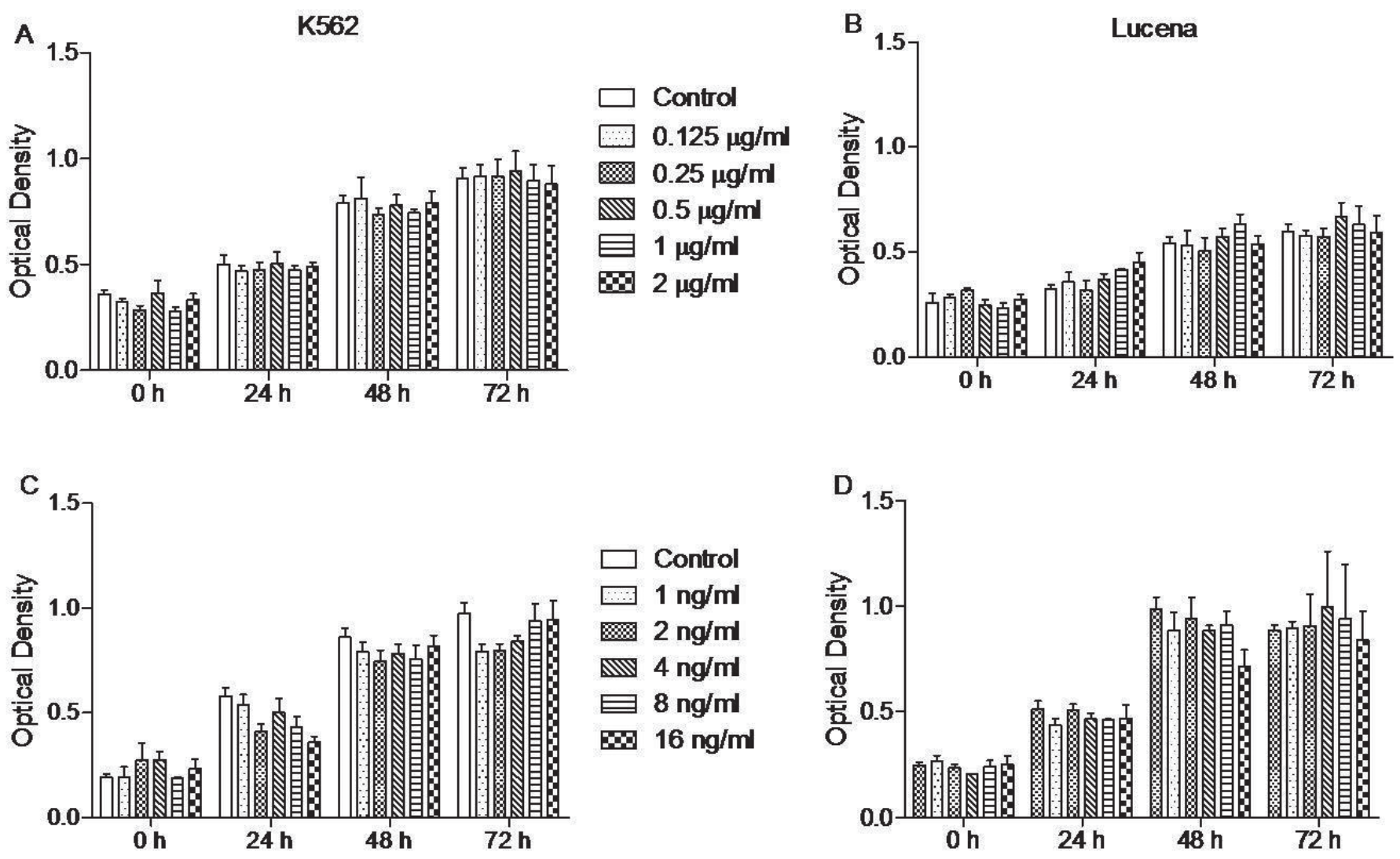

Figure 5: Effect of quercetin and propyl disulfide on cell viability Legend: Optical density of viable of K562 and MDR Lucena cells by the MTT assay, immediately (0), 24, 48 and 72 h after exposure to different concentrations of two onion compounds (quercetin or propyl disulfide). (A) K562 and (B) Lucena cells exposed to quercetin; and K562 (C) and (D) Lucena cells exposed to propyl disulfide. Data are expressed as mean +1 standard error. ${ }^{*}-$ indicates significant difference from the respective control at each exposure time $(p<0.05)$.
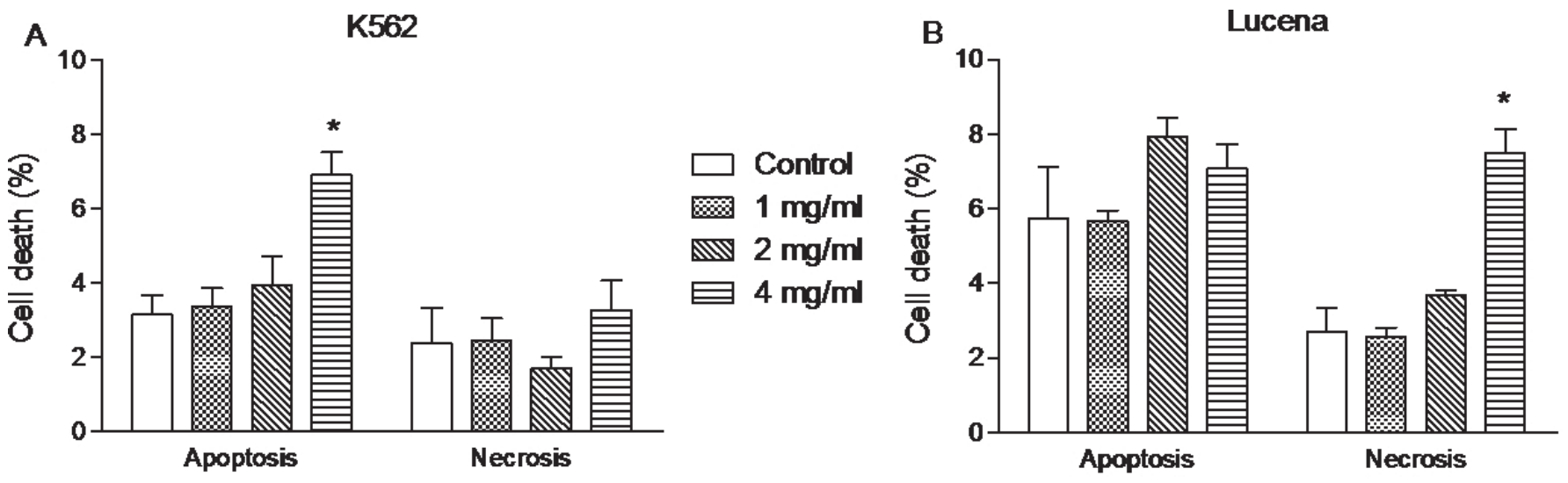

Figure 6: Apoptosis and necrosis

Legend: Quantification of cell death (\%) by apoptosis and/or necrosis in K562 (A) and Lucena (B) cell lines exposed for $24 \mathrm{~h}$ to 1,2 and $4 \mathrm{mg} / \mathrm{ml}$ of $\mathrm{OE}$. Data are expressed as mean + standard error. ${ }^{*}$ - indicates significant difference from the respective control $(\mathrm{p}<0.05)$. 

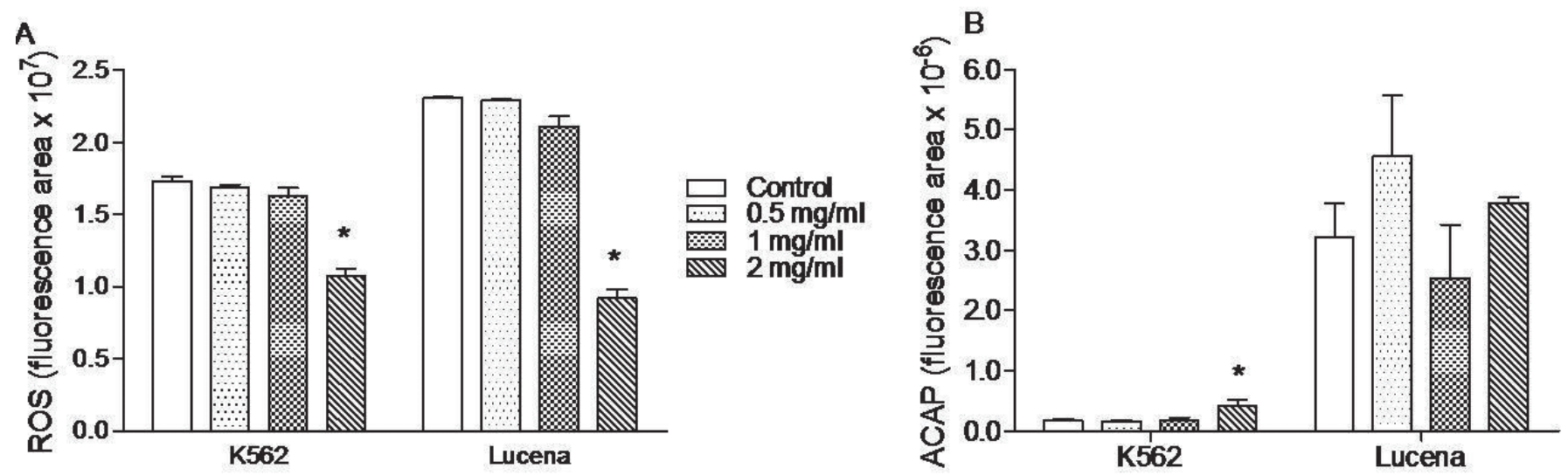

Figure 7. ROS and ACAP

Legend: Reactive oxygen species (ROS) production (A) and antioxidant capacity against peroxil radicals (ACAP) (B) in K562 and Lucena cells exposed for $24 \mathrm{~h}$ to $0.5,1$ and $2 \mathrm{mg} / \mathrm{ml}$ of OE. Data are expressed as mean + standard error. ${ }^{*}$ - indicates significant difference from the respective control $(p<0.05)$.

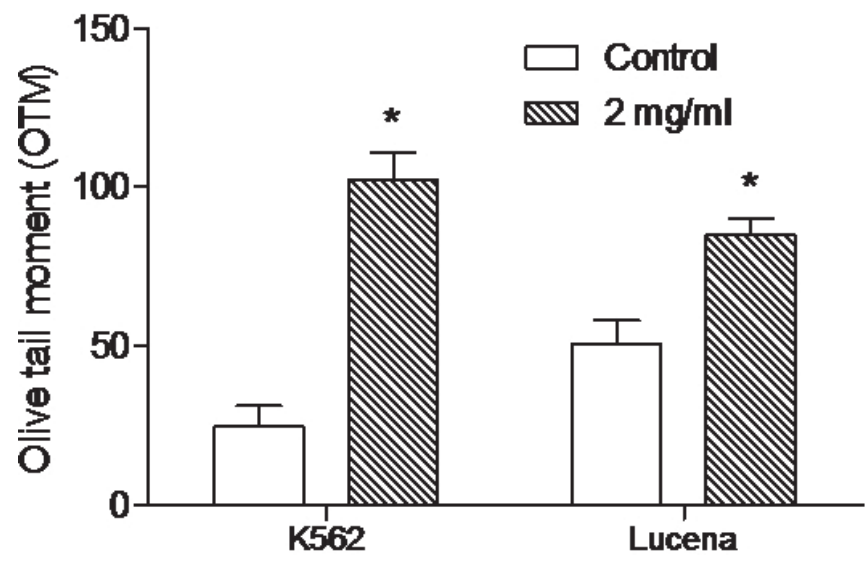

Figure 8: DNA damage

Legend: Quantification of DNA damage expressed by Olive tail moment (OTM) values in K562 (A) and Lucena (B) cell lines exposed for $24 \mathrm{~h}$ to $2 \mathrm{mg} / \mathrm{ml}$ of $\mathrm{OE}$. Data are expressed as mean + standard error. $*$ - indicates significant difference from the respective control $(p<0.05)$.

The results demonstrating that $\mathrm{OE}$ was cytotoxic in both K562 and Lucena cell lines, irrespective of MDR phenotype, are very important. Considering that drug resistance, both primary and acquired, is a major obstacle to advances in cancer chemotherapy, the identification of new substances with anti-MDR properties is urgently required (Fernandes et al., 2003). The capacity to overcome resistance mechanisms has been attributed to a few compounds, such as: the tripterpenes, betulinic, oleanolic (OA) and pomolic acids (PA), isolated from Physocarpus intermedius, Licania tomentosa and Chrysobalanus icaco, respectively. The OA was almost equally cytotoxic to Lucena cells overexpressing Pgp in comparison to their K562 sensitive counterpart, and the PA was highly effective in inhibiting the growth of both cell lines (Fernandes et al., 2003). As well, the lupane triterpene lup-28-al-20(29)-en-3-one, a synthetic product, was found to be a selective anti-leukemia compound and effective not only to K562 parental leukemia cells, but also to drug-resistant leukemia cells, producing similar cytotoxic effects (Hata et al., 2003). Fernandes et al. (2005), using HL-60 cells, showed that PA induced apoptosis by alteration of the mitochondrial membrane potential.

In this work the capacity of OE to induce apoptosis in K562 cells was verified. Other compounds of natural origin are also capable of inducing apoptosis in K562 or other leukemic cell lines as HL-60, ML-1, U937 and DS-19 (Jing et al., 1999; Ye et al., 2005; Huang et al., 2005; Sreekanth et al., 2007). However in the present study, an increase in apoptotic cells was verified only in the K562 cells while the Lucena cells presented a significant increase in the percentage of necrotic cells. The death of the Lucena cells by necrosis might be explained by the data that show that Pgp, which is over-expressed in MDR cells, may provide resistance to programmed cell death (Ruefli and Johnstone, 2003).

As mentioned before, NPTS suppresses the growth of HL-60 cells through the induction of apoptosis initiated by oxidative stress (Chang et al., 2005), suggesting an oxidant property associated with onion. However, based on the results obtained in this work, an antioxidant capacity for OE was verified, suggesting that oxidative stress is not involved in the induction of cell death. Although only the K562 cells have shown a significant increase in ACAP, the antioxidant capacity of $\mathrm{OE}$ can be argued because Lucena cells present a higher basal antioxidant capacity, which can explain this effect in these cells.

Others authors have also observed the antioxidant capacity of onion. Sujatha and Srivinas (1995) showed that the aqueous extract of Allium cepa inhibited lipid peroxidation (LPO) in human erythrocyte membrane. Similarly, Helen et al. (2000) verified a decrease in the LPO levels in liver, lung and heart of onion oil and nicotine treated rats and that this treatment increased activity of scavenging enzymes, such as catalase and superoxide dismutase (SOD) in all the tissues studied. El-Demerdash et al. (2005) showed that onion juice increased the activity of glutathione S-transferase antioxidant enzyme (GST) in rats with induced diabetes, which might be one of the defense mechanism in these animals to detoxify or neutralize the toxic metabolites generated in liver by diabetes. According to Park et al. (2009), the methanolic extract of onion attenuates ischemia/hypoxia-induced apoptosis in heart-derived H9c2 
cells and in rat hearts, through, at least in part, an antioxidant effect. Nuutila et al. (2003) affirm that the phenolic compounds of Allium plants contribute to their antioxidant properties. Moreover, it is interesting to remember that the OE utilized in this work contain quercetin, the major flavonol present in the onion (Prakash et al., 2007; Bonaccorsi et al., 2008), and that these compounds have a good correlation with antioxidant capacity (Santas et al., 2008).

The fact that OE did not provoke oxidative stress may explain the lack of resistance of the MDR cell line to this treatment. Trindade et al. (1999) showed that K562 and Lucena cells possess different sensitivities to UVA radiation, which causes damage in cells and tissues preferentially by oxidative stress. These authors demonstrated that MDR cells were very resistant to treatment and also to hydrogen peroxide. However, when the cell lines were exposed to UVB and UVC, which have DNA as preferential cellular target (Beer et al., 1993), the sensitivity was similar in both cell lines. Besides, Trindade et al. (2000) utilizing photodynamic action by methylene blue, which is well known for its capacity to strongly bind DNA (Floyd et al., 2004), demonstrated similar sensitivity among these and others cell lines. In this work we have shown the same sensitivity in both cell lines, supported also by similar DNA damage.

Thus, according to the results obtained in this work, it is possible to suggest that there is a synergistic effect of $\mathrm{OE}$ when compared to fractioned extracts and compounds. Its antioxidant capacity suggest that oxidative stress is not involved in the induction of cell death, and that the capacity to induce cell death by apoptosis in K562 cells or necrosis in Lucena cells might be due to DNA damage. It is important to note that $\mathrm{OE}$ was cytotoxic in both tumoral cell lines, irrespective of MDR phenotype, that permits also to suggest an anti-MDR action of OE.

\section{ACKNOWLEDGEMENTS}

This work was supported by the Programa de Pós-graduação em Ciências Fisiológicas - Fisiologia Animal Comparada (FURG). B.S.D. received a fellowship from PBIC program (CNPq). We are thankful to Jorge Alberto Castro Benitez and Robert Tew Boyle for revision of the manuscript.

\section{REFERENCES}

AMADO LL, GARCIA ML, RAMOS PB, FREITAS RF, ZAFALON B, FERREIRA JLR, YUNES JS, MONSERRAT JM (2009) A method to measure total antioxidant capacity against peroxyl radicals in aquatic organisms: application to evaluate microcystins toxicity. Sci Total Environ 407: 2115-2123.

AUGUSTI KT (1996) Therapeutic values of onion and garlic. J Exp Biol 34: 634-640.

BEER JZ, OLVEY KM, MILLER SA, THOMAS DP, GODAR DE (1993) Non-nuclear damage and cell lysis are induced by UVA, but not UVB or UVC, radiation in three strains of L5178Y cells. Photochem Photobiol 58: 676-681.

BONACCORSI P, CARISTI C, GARGIULLI C, LEUZZI U (2008) Flavonol glucosides in Allium species: A comparative study by means of HPLC-DAD-ESI-MS-MS. Food Chem 107: 1668-1673.

BOREK C (2005). Antioxidants and the prevention of hormonally regulated cancer. Pract med 2: 346-352.

BRAGA F, AYRES-SARAIVA D, GATTASS CR, CAPELLA MAM (2007) Oleanolic acid inhibits the activity of the multidrug resistance protein ABCC1 (MRP1) but not of the ABCB1 (P-glycoprotein): Possible use in cancer chemotherapy. Cancer Lett 248: 147-152.
CHANG H-S, YAMATO O, YAMASAKI M, KO M, MAEDE Y (2005) Growth inhibitory effect of alk(en)yl Thiosulfates derived from onion and garlic in human immortalized and tumor cell lines. Cancer Lett 223: 47-55.

CORZO-MARTÍNEZ M, CORZO N, VILLAMIEL M (2007) Biological properties of onions and garlic. Trends Food Sci Technol 18: 609-625.

EL-DEMERDASH FM, YOUSEF MI, ABOU EL-NAGA NI (2005) Biochemical study on the hypoglycemic effects of onion and garlic in alloxan-induced diabetic rats. Food and Chemical Toxicol 43: 57-63.

FERNANDES J, CASTILHO RO, DA COSTA MR, WAGNER-SOUZA K, KAPLAN MAC, GATTASS CR (2003) Pentacyclic triterpenes from Chrysobalanaceae species: cytotoxicity on multidrug resistant and sensitive leukemia cell lines. Cancer Lett 190: 165-169.

FERNANDES $\mathrm{J}$, WEINLICH R, CASTILHO RO, KAPLAN MAC, AMARANTE-MENDES GP, GATTASS CR (2005) Pomolic acid triggers mitochondria-dependent apoptotic cell death in leukemia cell line. Cancer Lett 219: 49-55.

FLOYD RA, SCHNEIDER JR JE, DITTMER DP (2004) Methylene blue photoinactivation of RNA viruses. Antiviral Res 61: 141-151.

FORD JM, HAIT WN (1990) Pharmacology of drugs that alter multidrug resistance in cancer. Pharmacology 42: 155-199.

FURLONG EB, BAISCH ALM, COLLA E, SOARES LAS (2003) Avaliação do potencial de compostos fenólicos em tecidos vegetais. Revista Vetor 13: 105-114

GOTTESMAN MM, PASTAN I (1993) Biochemistry of multidrug resistance mediated by the multidrug transporter. Annu Rev Biochem 62: 385-427.

HATA K, HORI K, OGASAWARA H, TAKAHASHI S (2003) Antileukemia activities of Lup-28-al-20(29)-en-3-one, a lupane triterpene. Toxicol Lett 143: 1-7.

HELEN A, KRISHNAKUMAR K, VIJAYAMMAL PL, AUGUSTI KT (2000) Antioxidant effect of onion oil (Allium cepa. Linn) on the damages induced by nicotine in rats as compared to alpha-tocopherol. Toxicol Lett 116: 61-68.

HOLLMAN PC, VAN-TRIJP JM, BUYSMAN MN, VAN-DER-GAAG MS, MENGELERS MJ, DEVRIES JH, KATAN MB (1997) Relative bioavailability of the antioxidant avonoid quercetin from various foods in man. FEBS Letters 418: 152-156.

HUANG WW, YANG JS, LIN CF, HO WJ, LEE MR (2005) Pycnogenol induces differentiation and apoptosis in human promyeloid leukemia HL-60 cells. Leukemia Res 29: 685-692.

JING Y, NAKAJO S, XIA L, NAKAYA K, FANG Q, WAXMAN S, HAN R (1999) Boswellic acid acetate induces differentiation and apoptosis in leukemia cell lines. Leukemia Res 23: 43-50.

KONCA K, LANKOFF A, BANASIK A, LISOWSKAB H, KUSZEWSKI T, GOZDZ S, KOZA Z, WOJCIK A (2003) A cross-platform public domain PC image-analysis program for the comet assay. Mutat Res 534: $15-20$.

LANKOFF A, BANASIK A, OBE G, DEPERAS M, KUZMINSKI K, TARCZYNSKA M, JURCZAK T, WOJCIK A (2003) Effect of microcystin-LR and cyanobacterial extract from Polish reservoir of drinking water on cell cycle progression, mitotic spindle, and apoptosis in CHO-K1 cells. Toxicol Appl Pharmacol 189: 204-213.

NUUTILA AM, PUUPPONEN-PIMIÄ R, AARNI M, OKSMANCALDENTEY, K-M (2003) Comparison of antioxidant activities of onion and garlic extracts by inhibition of lipid peroxidation and radical scavenging activity. Food Chem 81: 485-493.

PARK S, KIM M, LEE DH, LEE SH, BAIK EJ, MOON C, PARK SW, KO EY, OH S, JUNG Y (2009) Methanolic extract of onion (Allium cepa) attenuates ischemia/hypoxia-induced apoptosis in cardiomyocytes via antioxidant effect. Eur J Nutr 48: 235-242.

PRAKASH D, SINGH BM, UPADHYAY G (2007) Antioxidant and free radical scavenging activities of phenols fromonion (Allium cepa). Food Chem 102: 1389-1393.

ROLDÁN E, SÁNCHEZ-MORENO C, DE ANCOS B, CANO MP (2008) Characterisation of onion (Allium cepa L.) by-products as food ingredients with antioxidant and antibrowning properties. Food Chem 108: 907-916.

RUEFLI AA, JOHNSTONE RW (2003) A role for P-glycoprotein in regulating cell growth and survival. Clin Appl Immunol Rev 4: 31-47.

RUMJANEK VM, LUCENA M, CAMPOS MM, MARQUES-SILVA VM, MAIA RC (1994) Multidrug resistance in leukemias: the problem and some approaches to its circumvention. Ciênc Cult 46: 63-69.

SALEHEEN D, ALI SA, YASINZAI MM (2004) Antileishmanial activity of aqueos onion extract in vitro. Fitoterapia 75: 9-13.

SANTAS J, CARBÓ R, GORDON MH, ALMAJANO MP (2008) 
Comparison of the antioxidant activity of two Spanish onion varieties. Food Chem 107: 1210-1216.

SEKI T, TSUJI K, HAYATO Y, MORITOMO T, ARIGA T (2000) Garlic and onion oils inhibit proliferation and induce differentiation of HL-60 cells. Cancer Lett 160: 29-35.

SINGH NP, MCCOY MT, TICE RR, SCHEIDER EL (1988) A simple technique for quantitation of low levels of DNA damage in individual cells. Exp Cell Res 237: 3-4.

SLIMESTAD R, FOSSEN T, VAGEN IM (2007) Onions: A Source of Unique Dietary Flavonoids. J Agric Food Chem 55: 10067-10080.

SREEKANTH D, ARUNASREE MK, ROY KR, CHANDRAMOHAN REDDY T, REDDY GV, REDDANNA P (2007) Betanin a betacyanin pigment purified from fruits of Opuntia ficus-indica induces apoptosis in human chronic myeloid leukemia Cell line-K562. Phytomedicine 14: 739-746.

STEINERT SA, STREIB-MONTEE R, LEATHER JM (1998) DNA damage in mussels at sites in San Diego Bay. Mutat Res Fund Mol Mech Mut 399: 65-85.

SUJATHA R, SRIVINAS L (1995) Modulation of lipid peroxidation by dietary components. Toxicol in vitro 9: 231-236.
TEYSSIER C, AMIOT MJ, MONDY N (2001) Effect of onion consumption by rats on hepatic drug-metabolizing enzymes. Food Chem Toxicol 39: 981-7.

TRINDADE GS, CAPELLA MAM, CAPELLA LS, AFFONSO-MITIDIER OR, RUMJANEK VM (1999) Differences in sensitivity to UVC, UVB and UVA radiation of a multidrug-resistant cell line overexpressing P-glycoprotein. Photochem Photobiol 69: 694-699.

TRINDADE GS, FARIAS SLA, RUMJANEK VM, CAPELLA MAM (2000) Methylene blue reverts multidrug resistance: sensitivity of multidrug resistant cells to this dye and its photodynamic action. Cancer Lett 14: 161-167.

TSURUO T, LIDA H, OHKOCHI E, TSUKAGOSHI S, SAKURAI Y (1983) Establishment and properties of a vincristine-resistant human myelogenous leukemia K562. J Cancer Res 74: 751-758.

WACH A, PYRZYNSKA K, BIESAGA M (2007) Quercetin content in some food and herbal samples. Food Chem 100: 699-704.

YE C-L, QIAN F, WEI D-Z, LU Y-H, LIU J-W (2005) Induction of apoptosis in K562 human leukemia cells by $2^{\prime}, 4^{\prime}$-dihydroxy-6' methoxy-3',5'-dimethylchalcone. Leukemia Res 29: 887-892. 